nationalisme in Japan' (143). Ik moet bekennen dat die gedachte tijdens het lezen van het boek van Van Poelgeest niet bij mij was opgekomen.

J. C. H. Blom

H. van Goor, Vlucht uit het dodendal van de Neckar. Het verhaal van een dwangarbeider tijdens de tweede wereldoorlog (Bedum: Uitgeverij Profiel, 1989, 299 blz., f46,50, ISBN 9070287 $846)$.

Het initiatief tot publikatie van dit boek is mede afkomstig van de in 1987 opgerichte Vereniging dwangarbeiders Nederland tweede wereldoorlog, die onder meer de geschiedschrijving over het lot van de tewerkgestelde Nederlanders wil bevorderen. De schrijver van Vlucht uit het dodendal van de Neckar wil echter vooral begrip kweken voor de positie van de Nederlandse tewerkgestelden gedurende de bezettingstijd. Direct in het begin verklaart hij dat zij 'na hun terugkeer in Nederland soms verkeerd werden beoordeeld' en 'dat was natuurlijk niet eerlijk, want [zij] hadden immers meestal geen keus'. Afgezien van deze poging tot rehabilitatie van deze groep slachtoffers van de tweede wereldoorlog, houdt Van Goor de lezer voor dat ' een eventuele Derde Wereldoorlog meer vernietiging en ellende zal veroorzaken dan de vorige Wereldoorlogen tezamen'. Goede bedoelingen alleen zijn echter niet voldoende om een leesbaar en interessant boek te produceren. Als Van Goor zich had beperkt tot zijn persoonlijke ervaringen als dwangarbeider, was zijn verhaal bruikbaar geweest als egodocument. Maar omdat 'ter wille van de leesbaarheid ... werkelijkheid en fictie wel eens met elkaar [zijn] verweven', is dit praktisch uitgesloten. Bovendien bespreekt de schrijver zo ongeveer alles wat hem terugdenkend aan de oorlog maar te binnen geschoten moet zijn. Zo krijgt de lezer niet alleen een uitvoerige beschrijving van jeugdherinneringen voorgezet, maar ook uiteenzettingen over de activiteiten van het verzet in Twente en zelfs over de balans van de tweede wereldoorlog, de persoon van Hitler en de jodenvervolging. Hoewel het boek voor intern gebruik binnen de vereniging misschien geschikt is, kan het niet worden aangemerkt als een serieuze bijdrage aan de geschiedschrijving over dit aspect van de tweede wereldoorlog.

C. M. Kristel

W. H. Acksen, De belevenissen van een reserve-officier in vrede en oorlog. Hoe de militaire dienstplicht mijn burgerleven heeft beïnvloed (De Bilt: W. H. Acksen (Biltstein 28,3732 GT De Bilt), s. a., 126 blz., f20,-, ISBN 909002323 2).

De vraag waarom iemand zijn herinneringen te boek stelt, valt bij dit werkje gemakkelijk te beantwoorden. De auteur geboren in 1911, wil getuigen, en wel van de positieve invloed die de dienstplicht op zijn maatschappelijke loopbaan heeft gehad.

Tot mei 1940 wijken zijn lotgevallen niet wezenlijk af van die van vele andere telgen uit de burgerij: een HBS-opleiding, de crisis die verdere studie verhinderde, het spook der werkloosheid en, uiteindelijk, een betrekking. Op 3 oktober 1930 werd de binnendienst van de verkoopafdeling van Philips ingeruild voor het groene uniform: de opleiding bij de School voor reserve-officieren infanterie te Kampen, gevolgd door een parate plaatsing te Venlo. Van deze 
periode van eerste oefening weet de auteur een aardig sfeerbeeld te schetsen; eens te meer blijkt dat het besef het militaire handwerk ooit in de praktijk te moeten brengen, bij de opleiding niet sterk leefde. Vervolgens was Acksen blij met een ambtelijke carrière in Wassenaar: een tijd van zelfstudie.

Met de mobilisatie komen we bij de kern van het boek, de jaren 1939-1949. De mobilisatie en de meidagen beleefde onze hoofdpersoon als plaatsvervangend commandant van de mitrailleurcompagnie van III-17 R. I. Zijn relaas voegt evenwel niets toe aan het bestaande beeld: graven en oefenen in de Peel, verplaatsingen en tot slot de capitulatie zonder gevechtscontact te hebben gehad. Na terugkeer uit krijgsgevangenschap hernam het leven slechts ogenschijnlijk zijn normale loop: als leidend functionaris in de distributiedienst - eerst te Wassenaar, na augustus 1942 te Voorburg - verleende hij daarvoor te veel steun aan het verzet, etaleerde hij zijn antiDuitse gevoelens te openlijk en verschafte hij joodse medeburgers onderdak. Op 15 juni 1943 werd Acksen gearresteerd. Het zevende hoofdstuk - het boek telt tien - handelt over zijn ervaringen achter Duits prikkeldraad: Oranje-hotel, Vught, Werkcommando op de vliegbasis Eindhoven, Vught, 'Himmelfahrtcommando' te Venlo en Amersfoort. De status van reserveofficier bracht hier ten lange leste en na interventie van buitenaf redding: afvoer in Duitse krijgsgevangenschap in juli 1944. Saillant detail vormt een passage over prof. P. Lieftinck in het kamp Neubrandenburg: cursusleider èn stimulator van discussies over na-oorlogse geldzuiveringsmaatregelen.

$\mathrm{Na}$ terugkeer in Nederland volgde weldra uitzending overzee. In Indië diende Acksen als bataljonscommandant en in staffuncties. Zijn relaas over deze periode is kenmerkend voor het boek: een sober, zakelijk relaas van eigen handelen. Het 'hoe en waarom' van gebeurtenissen ontbreekt veelal. Na demobilisatie volgen een voorpoedige carrière in de vaderlandse gezondheidszorg: management-ervaring, improvisatie en beslisvaardigheid, opgedaan en ontwikkeld als officier, wierpen hierbij hun vruchten af. In het voorlaatste hoofdstuk staat centraal de moeizame strijd van economisch directeuren in de gezondheidszorg — van wie Acksen er een was - om medici enig gevoel voor efficiency en kosten bij te brengen. De band met het leger bleef tot 1964 in tact; toen was het ook einde oefening voor de reserve luitenant-kolonel Acksen.

Samenvattend: Een ontwapenend boekje met een sympathiek aandoende inhoud, eerder bestemd voor consumptie bij de familiehaard dan voor de historicus die op zoek is naar nieuwe feiten en gezichtspunten.

P. H. Kamphuis 


\section{De mythe van de Spaanse inquisitie in de Nederlanden van de zestiende eeuw}

\section{WERNER THOMAS}

Op 1 november 1478 vaardigde paus Sixtus IV op verzoek van Ferdinand van Aragón en Isabella van Castilië de bulle Exigit sincerae devotionis affectus uit, waarmee hij de katholieke koningen toestond in het koninkrijk Castilië een inquisitietribunaal op te richten en eigenhandig de inquisiteurs ervan te benoemen. In de bulle verduidelijkte de paus dat het vorstenpaar daarop aangedrongen had om beter de strijd te kunnen aanbinden met de vele judaizantes, tot het christendom bekeerde joden die het niet zo nauw namen met hun nieuwe geloof en, veelal in het geheim, hun oude godsdienst bleven aanhangen ${ }^{1}$. Inderdaad vervolgde het Spaanse heilig officie ${ }^{2}$ in de eerste dertig à veertig jaar van zijn bestaan bijna uitsluitend schijnbaar bekeerde joden, maar daarna richtte het ook zijn aandacht op andere religieuze dissenters: schijnbaar bekeerde mohammedanen, aanhangers van Erasmus, alumbrados ${ }^{3}$, protestanten, heksen en tovenaars, later verlichte denkers en liberalen. Naarmate de contrareformatie, ingezet door het concilie van Trente, meer en meer op gang kwam, verschenen eveneens diverse overtreders van de heersende morele code in de audiëntiezalen: vloekers en lasteraars, bigamisten en homoseksuelen. Al die tijd profileerde de inquisitie zich als verdedigster van het orthodoxe, rooms-katholieke geloof op het Iberisch schiereiland. Om haar taak naar behoren te vervullen hanteerde zij een gans arsenaal van uitzonderingsmaatregelen en wendde zij een wel zeer aparte vorm van procesvoeren aan, waarvan de geheimhouding het meest in het oog springende kenmerk was. Behalve zij die als getuige of beschuldigde te maken kregen met de instelling, wisten slechts weinig mensen wat er zich afspeelde in de kerkers en audiëntiezalen van het tribunaal. Dat leidde natuurlijk tot talrijke gissingen en veronderstellingen, die inquisitie en inquisiteurs — niet altijd terecht — de faam bezorgden wreed en genadeloos te zijn.

1 Zij werden ook marranos, letterlijk 'zwijnen', genoemd. Een converso, (nieuw-)bekeerde, hoefde daarentegen niet altijd een judaizante te zijn. Zijn bekering kon immers nog altijd oprecht zijn. Vrij snel beschouwden de oud-christenen alle conversos echter als potentiële marranos, ongeacht de oprechtheid van hun bekering.

2 De termen 'tribunaal' en 'heilig officie' worden in dit artikel steeds als synoniem voor 'Spaanse inquisitie' gebruikt.

3 Aan het lutheranisme verwante beweging die evenals Luther de sacramenten, ceremonies, goede werken en boetedoening afwees. De ideeën van de alumbrados gingen echter nog veel verder. Het zich openstellen voor God, die tijdens het gebed hun ziel en geest binnendrong, stelden ze boven alles. Ze probeerden tijdens hun bijeenkomsten een toestand van extase te bereiken om zich totaal ontvankelijk te stellen voor Hem. Het mystieke karakter van hun gebedsstonden maakte hen extra verdacht bij de inquisitie. Cf. Antonio Márquez, Los alumbrados (2e dr.; Madrid, 1980); Bernardino Llorca, La Inquisición española y los alumbrados (1509-1667) (herziene uitgave; Salamanca, 1980). 